\title{
PENGARUH LATAR BELAKANG PENDIDIKAN ORANG TUA DAN GAYA BELAJAR TERHADAP HASIL BELAJAR MATEMATIKA
}

\author{
Sukiyanto $^{1}$, Zuhriyyah Hidayati ${ }^{2}$, Niswatin Aliyah ${ }^{3}$ \\ Pendidikan Guru Madrasah Ibtidaiyah, STIT Al-Fattah Siman Lamongan,
}

INFO ARTIKEL

Diterima:15-02-2020

Disetujui:17-02-2020

Kata Kunci:

Gaya belajar, Hasil

belajar matematika,

Pendidikan orang tua.

\begin{abstract}
Abstrak: Tujuan penelitian ini adalah untuk menganalisis pengaruh latar belakang pendidikan orang tua, gaya belajar dan hasil belajar matematika. Penelitian ini menggunakan pendekatan kuantitatif dengan sampel 38 siswa. Teknik pengumpulan data menggunakan teknik angket dan dokumentasi. Teknik analisis data meliputi analisis deskriptif, analisis regresi linear berganda dan uji t. Hasil penelitian menunjukkan bahwa: 1) kondisi latar belakang pendidikan orang tua berada pada kategori sedang, sebagian besar orang tua memilki dasar pendidikan yang memadai untuk bisa membimbing dan mengarahkan untuk mencapai hasil belajar yang lebih baik. Sedangkan gaya belajar peserta didik mayoritas menggunakan gaya belajar auditory, siwa cenderung memanfaatkan indra pendengarannya untuk memahami apa yang dia pelajari misalnya dengan cara mendengar seperti ceramah, radio, berdialog, dan berdiskusi. Selain itu, bisa juga mendengarkan melalui nyanyian dan lagu; 2) latar belakang pendidikan orang tua memiliki $t$ hitung sebesar 1,102 < 1,68 dengan signifikasi 0,278>0,05. Karena thitung $<t$ tabel dan sig. 0,278>0,05 secara parsial variabel latar belakang pendidikan orang tua tidak berpengaruh terhadap hasil belajar matematika siswa.
\end{abstract}

\begin{abstract}
The purpose of this study is to analyze the influence of parents' educational background, learning styles and mathematics learning outcomes. This study uses a quantitative approach with a sample of 38 students. Data collection techniques using questionnaires and documentation. Data analysis techniques include descriptive analysis, multiple linear regression analysis and t test. The results showed that: 1) the condition of parents' educational background is in the moderate category, most parents have an adequate educational foundation to be able to guide and direct to achieve better learning outcomes. Whereas the majority of students' learning styles use auditory learning styles, students tend to utilize their sense of hearing to understand what they are learning for example by listening such as lectures, radio, dialogue, and discussion. Besides that, you can also listen through songs and songs; 2) parents' educational background has a t count of $1.102<1.68$ with a significance of $0.278>0.05$. Because $t$ arithmetic $<t$ table and sig. 0.278> 0.05 partially the educational background variables of the parents had no effect on student mathematics learning outcomes.
\end{abstract}

Alamat Korespondensi:

Zuhriyyah Hidayati

Niswatin Aliyah 
KARANGAN: Jurnal Kependidikan, Pembelajaran, dan Pengembangan, Vol 02, No 01, Bln Feb, Tahun 2020, Hal 46-63

Instansi:

Pendidikan Guru Madrasah Ibtidaiyah, STIT Al-Fattah Siman Lamongan,

Kompleks P.P Al Fattah, Desa Siman, Kecamatan Sekaran, Kabupaten

Lamongan, Jatim

Sukiyanto@stitaf.ac.id

Pendidikan adalah usaha sadar untuk mengembangkan kepribadian anak baik di luar ataupun di dalam sekolah dan berlangsung seumur hidup. Pendidikan merupakan wahana yang sangat penting untuk meningkatkan dan mengembangkan kualitas sumber daya manusia (SDM) yang turut berpengaruh terhadap kelangsungan suatu bangsa sebagaimana yang tertera dalam UU No. 20 Tahun 2003 yang menyatakan bahwa "Pendidikan merupakan usaha sadar dan terencana untuk mewujudkan suasana belajar dan proses pembelajaran agar peserta didik secara aktif mengembangkan potensi dirinya untuk memiliki kekuatan spiritual keagamaan, pengendalian diri, kepribadian, kecerdasan, akhlak mulia, serta keterampilan yang diperlukan dirinya, masyarakat, bangsa dan negara"

Pendidikan menempatkan posisi dalam kedudukan yang sangat penting dan sentral di sepanjang masa. Pendidikan merupakan tiang bagi kemajuan, bahkan sebagai basis dari segala langkah atau pekerjaan (Zainuddin, 2011). Berdasarkan kedua pendapat tersebut dapat diketahui pentingnya pendidikan dalam kehidupan manusia. Sekolah merupakan salah satu sarana untuk mencapai pendidikan yang berkualitas. Melalui sekolah siswa dapat membentuk karakter dan berubah menjadi pribadi yang lebih positif dan perubahan positif tersebut dapat direalisasikan melalui proses pembelajaran. Sukses tidaknya sebuah pembelajaran dapat dilihat dari tercapainya tujuan pembelajaran yang telah ditentukan sebelumnya dan itu bisa di lihat dari hasil belajar peserta didik.

Menurut Purwanto, (2013) hasil belajar merupakan perubahan perilaku siswa akibat belajar, perubahan tersebut disebabkan karena telah memahami atau menguasai materi yang diajarkan yang telah ditetapkan hasilnya. Dalam proses pembelajaran, pencapaian hasil belajar harus selalu diusahakan dapat meningkat dengan baik (Sudirman, 2007). Hasil belajar disini mencakup kemampuan kognitif, afektif, dan psikomotorik. Kemampuan tersebut biasanya ditunjukkan dengan nilai tes atau angka yang diberikan oleh guru.

Matematika merupakan ilmu universal yang berperan sangat penting dalam berbagai disiplin ilmu, dan mampu mengembangkan daya pikir manusia, Besarnya peranan tersebut menjadikan matematika sebagai mata pelajaran wajib di sekolah dasar, Menengah maupun Kejuruan dan perlunya penguasaan konsep yang kuat sejak dini, serta dapat menumbuhkan kemampuan siswa dalam berpikir logis, analitis, sistematis, kritis, kreatif dan bekerja sama secara efektif dengan tujuan agar siswa dapat memiliki kemampuan memperoleh, mengelola, memanfaatkan informasi dan kompetitif (Yanto, 2018). Hasil belajar matematika adalah tolak ukur atau patokan yang menentukan tingkat keberhasilan serta kemampuan yang dimiliki oleh peserta didik setelah menerima pengalaman belajar matematikanya baik pengetahuan, sikap maupun ketrampilannya.

Berdasarkan hasil observasi yang dilaksanakan di MI Ma'arif NU Sekaran diketahui bahwa skor rata-rata hasil belajar matematika peserta didik bervariasi, 
ada yang mendapat nilai sangat baik dan adapula yang mendapat nilai cukup baik namun secara keseluruhan skor yang di dapat peserta didik sudah diatas kriteria ketuntasan minimal (KKM). Untuk mencapai keberhasilan belajar secara maksimal harus diperhatikan faktor-faktor apa saja yang mempengaruhi. Adapun faktor yang mempengaruhi keberhasilan belajar siswa dapat diklasifikasikan ke dalam dua golongan, yaitu faktor yang berasal dari dalam diri siswa (internal) dan faktor yang berasal dari luar diri siswa (eksternal). Faktor dari diri siswa, antara lain kesiapan mental dan fisik, sikap terhadap pendidikan, kebiasaan belajar, motivasi berprestasi, jenis kelamin, kesehatan, dan umur. Faktor dari luar diri siswa antara lain tingkat pendidikan orangtua, penghasilan orang tua, jenis pekerjaan orang tua, gaya belajar yang diterapkan, situasi belajar mengajar, karakteristik kurikulum, dan karakteristik kelompok siswa. Dan faktor yang mempengaruhi hasil belajar peserta didik diantaranya adalah latar belakang tingkat pendidikan orang tua dan gaya belajar peserta didik.

Tingkat pendidikan adalah jenjang pendidikan formal tertinggi yang pernah ditempuh dan dinyatakan dengan ijazah, sebagaimana yang tertuang dalam UUD 1945 Sisdiknas No.20 Tahun 2003, BAB VI pasal 13 yang menyatakan bahwa jenjang pendidikan formal terdiri atas pendidikan dasar, pendidikan menengah dan pendidikan tinggi. Faktor latar belakang tingkat pendidikan orang tua oleh sebagian peneliti dianggap merupakan sesuatu yang besar pengaruhnya terhadap perkembangan anak. Sebagian pakar beranggapan bahwa latar belakang tingkat pendidikan orang tua ini berkorelasi positif dengan cara mereka mengasuh anak, sementara pengasuhan anak berhubungan dengan perkembangan anak. Hal ini berarti makin tinggi pendidikan terakhir orang tua akan makin baik pula cara pengasuhannya dan akibatnya perkembangan anak terpengaruh dan dapat berjalan secara positif. Sebaliknya makin rendah tingkat pendidikan orang tua akan kurang baik dalam mengasuh anak, sehingga perkembangan anak berjalan kurang menguntungkan (Sulistyaningsih, 2005).

Sementara di pihak lain beberapa fakta menunjukkan bahwa latar belakang pendidikan yang tinggi tidak menjamin orang tua akan memberikan perhatian dan motivasi terhadap anaknya hal ini dikarenakan mereka memiliki keterbatasan waktu akibat pekerjaan yang mereka lakukan dan adapula orang tua yang memiliki latar belakang rendah namun memiliki kesadaran yang tinggi akan pentingnya pendidikan bagi putra dan putri mereka, sehingga mereka mencari informasi terkait anak-anak dan meluangkan waktu mereka untuk membantu dan mendampingi putra dan putri mereka dalam menyelesaikan tugas belajarnya dan karena perhatian yang lebih tersebut menjadikan putra dan putri mereka memiliki motivasi belajar yang tinggi sehingga hasil belajar merekapun tinggi dan tak kalah dengan anak yang memiliki orang tua dengan latar belakang tingkat pendidikan yang tinggi.

Dalam sebuah penelitian yang dilaksanakan di India, Chile, Iran dan Thailand yang dilaporkan oleh Thorndike menjelaskan bahwa latar belakang keluarga itu dapat menjelaskan perubahan prestasi belajar antara 1,5\% sampai 8,7 $\%$. Jika dikontrol dengan indikator-indikator yang berasal dari sekolah seperti kualitas pengajaran, fasilitas sekolah, jumlah siswa dalam kelas dan sebagainya, 
KARANGAN: Jurnal Kependidikan, Pembelajaran, dan Pengembangan, Vol 02, No 01, Bln Feb, Tahun 2020, Hal 46-63

hasil tes menunjukkan sumbangan latar belakang keluarga tidak signifikan (Iif \& Sofan, 2014).

Selain faktor eksternal yakni latar belakang pendidikan orang tua terdapat juga faktor internal yakni faktor yang berasal dari individu itu sendiri salah satunya adalah gaya belajar. Gaya belajar adalah cara yang cenderung dipilih seseorang untuk menerima informasi dari lingkungan dan memproses informasi tersebut (Prihandoko, 2006). Tiap orang memiliki kecendrungan gaya belajar sendiri-sendiri oleh karena itu perlu sekali bagi seorang pendidik terlebih orang tua khususnya mengetahui gaya belajar anak agar nantinya bisa menyusun pembelajaran yang sesuai dengan gaya belajar anak sehingga lebih mempermudah anak dalam memahami materi yang disampaikan. jika seseorang telah akrab dengan gaya belajarnya sendiri, maka dia dapat membantu dirinya sendiri dalam belajar lebih cepat dan lebih mudah (Porter dan Hernacki, 2013) yang pada akhirnya akan berpengaruh pula terhadap hasil belajar anak. Berdasarkan fenomena di atas menunjukkan bahwa hasil belajar dipengaruhi oleh beberapa faktor diantaranya adalah latar belakang pendidikan orang tua dan gaya belajar.

\section{METODE}

Penelitian ini menggunakan penelitian kuantitatif, Hasil penelitian yang berwujud data kuantitatif akan dianalisis dengan statistik. Penelitian ini menggunakan pendekatan korelasi dimana penelitian ini bertujuan untuk mengetahui hubungan antara dua variabel atau lebih (Yanto \& Maulidah, 2019). Penelitian ini digolongkan kedalam penelitian ex post facto. Ex post facto berarti setelah kejadian. Dalam penelitian ex post facto, peneliti menyelidiki permasalahan dengan meninjau vairabel-variabel. Ex post facto merupakan pencarian empirik yang sistematik dan ilmuan tidak dapat mengontrol langsung variabel bebas karena peristiwanya telah terjadi atau karena menurut sifatnya tidak dapat dimaniulasi (Sudaryono dkk., 2013).

Instrumen yang digunakan dalam penelitian ini adalah berupa angket. Angket yang digunakan dalam penelitian ini adalah angket tertutup, yaitu angket yang telah dilengkapi dengan pilihan jawaban sehingga siswa hanya memberi tanda pada jawaban yang telah dipilih. Instrument angket yang digunakan dalam penelitian ini adalah untuk mengungkapkan data tentang gaya belajar peserta didik. Pengembangan instrumen dilakukan melalui beberapa cara yaitu menyusun indikator variabel penelitian, menyusun kisi-kisi instrument, kemudian melakukan uji coba instrument dengan menggunakan uji validitas dan reliabilitas instrumen. Teknik pengukuran angket dalam penelitian ini adalah menggunakan skala likert. Skala likert ini digunakan untuk mengukur sikap, pendapat dan persepsi seseorang tentang fenomena atau geala sosial yang terjadi. Skala likert ini berisi pernyataanpernyataan mengenai obyek sikap yang sesuai dengan indikator-indikator variabel sebagai dasar penyusunan skala dan setiap penyataan memuat empat alternatif jawaban yaitu selalu (S), sering (SR), kadang-kadang (K) dan tidak pernah (TP), Kisi-kisi instrumen dalam penelitian yang akan dilakukan ini berupa pertanyaan atau angket. 
Table 1. Kisi-kisi instrument gaya belajar peserta didik

\begin{tabular}{clll}
\hline Variabel & \multicolumn{1}{c}{ Definisi Operasional } & \multicolumn{2}{c}{ Indikator } \\
\hline Gaya Belajar $\left(\mathrm{X}_{2}\right)$ & Gaya belajar adalah cara yang & Visual, & Auditori, \\
& disukai dan mempermudah sesorang & Kinestetik. & \\
& dalam memproses, memahami dan & & \\
& menyimpan informasi yang & \\
diperoleh. & & \\
& & & \\
\hline
\end{tabular}

Teknik pengumpulan data yang digunakan dalam penelitian ini adalah :1) Metode Angket: merupakan teknik pengumpulan data yang dilakukan dengan cara memberi seperangkat pertanyaan atau pernyataan tertulis kepada responden; 2) Dokumentasi: digunakan untuk mengambil data penelitian yang bersumber pada tulisan yang berupa catatan, transkrip, buku, surat kabar, majalah, prasasti, notulen rapat, lengger, agenda; dan digunakan untuk memperoleh data mengenai hasil belajar peserta didik, meliputi buku-buku yang relevan, laporan kegiatan, foto, film dokumenter dan lain-lain yang relevan dengan penelitian. Pedoman dokumentasi dalam penelitian ini digunakan untuk memperoleh data terkait pendidikan terakhir orang tua dan hasil belajar peserta didik. Dalam penelitian ini nilai hasil belajar yang kami ambil adalah nilai ulangan tengah semester yang diperoleh peserta didik.

Teknik analisis data ini merupakan langkah yang digunakan untuk menjawab rumusan masalah dalam penelitian, tujuannya adalah untuk mendapatkan kesimpulan dari data yang di peroleh. Kesalahan dalam menentukan alat analisis dapat berakibat fatal terhadap kesimpulan yang dihasilkan dan hal ini akan berdampak lebih buruk lagi terhadap penggunaan dan penerapan hasil penelitian tersebut.

Adapaun analisis data dalam penelitian ini adalah:

\section{Analisis Deskriptif}

Analisis ini digunakan untuk mengetahui bagaimana tingkat pendidikan orang tua, gaya belajar dan hasil belajar siswa. Analisis statistik deskriptif adalah statistik yang digunakan untuk menganalisis data dengan cara mendeskripsikan atau menggambarkan data yang telah terkumpul sebagaimana adanya tanpa bermaksud membuat kesimpulan yang berlaku untuk umum atau generalisasi. Analisis ini digunakan untuk mengetahui tingkat pendidikan orang tua, gaya belajar dan hasil belajar siswa.

2. Uji Asumsi

Uji asumsi ini dilakukan sebagai syarat sebelum melakukan analisis regresi berganda karena dalam analisis regresi berganda meniscayakan terpenuhinya bebrapa asumsi dasar sebelum dilakukan tahap pengujian lebih lanjut. Uji asumsi dalam penellitian ini menggunakan uji normalitas dan uji linearitas.

a. Uji Normalitas

Uji normalitas dalam penelitian ini dilakukan dengan bantuan aplilasi SPSS. Dasar pengambilan keputusan dalam uji normalitas yaitu jika nilai signifikan (sig) lebih besar dari 0,05 maka data penelitian berdistribusi normal sebaliknya jika nilai signifikasi kurang dari 0,05 maka data penelitian tidak bersdistribusi normal.

b. Uji Linearitas

Uji linieritas adalah prosedur yang digunakan untuk mengetahui status linier suatu distribusi data penelitian (Winarsunu, 2009). Secara umum uji linearitas ini 
KARANGAN: Jurnal Kependidikan, Pembelajaran, dan Pengembangan, Vol 02, No 01, Bln Feb, Tahun 2020, Hal 46-63

bertjuan untuk mengetahui apakah dua variable mempunyai hubungan yang linier secara signifikan atau tidak.

Dasar pengambilan keputusan dalam uji llinearitas dapat dilakukan dengan dua cara yaitu:

1) Membandingkan nilai signifikasi (sign.) dengan 0,05 .

a) Jika nilai deviation from linearity signifikasinya $>0,05$ maka ada hubungan yang linier secara signifikan antara variable independent dan variabel depedent.

b) Jika nilai deviation from linearity signifikasinya $<0,05$ maka tidak ada hubungan yang linier secara signifikan antara variable independent dan varabel depedent.

2) Membandingkan nilai $F$ hitung dengan $F$ tabel

a) Jika nilai $\mathrm{F}$ hitung > F tabel, maka ada hubungann yang linear secara signifikan antara variable independent dan varabel depedent.

b) Jika nilai $\mathrm{F}$ hitung $<\mathrm{F}$ tabel, maka tidak ada hubungan yang liner secara signifikan antara variable independent dan varabel depedent.

c. Uji Hipotesis.

Uji hpotesis yang dilakukan dalam penelitian ini menggunakan uji analisis regresi berganda dan uji $t$.

a. Analisis regresi berganda

Analisis regresi berganda merupakan suatu metode atau teknik analisis hipotesis penelitian untuk menguji ada tidaknya pengaruh antara variabel satu dengan variabel lain yang dinyatakan dalam bentuk persamaa matematik (regresi). adalah analisis regresi berganda ini berfungsi untuk mencari pengaruh dua variabel bebas atau lebih $\left(\mathrm{X}_{1}\right),\left(\mathrm{X}_{2}\right),\left(\mathrm{X}_{3}\right), \ldots,\left(\mathrm{X}_{\mathrm{n}}\right)$ dengan satu variabel terikat $(\mathrm{Y})$. Persamaan regresi berganda dapat dirumuskan:

$$
\mathrm{Y}=a+b_{1} \mathrm{X}_{1}+b_{2} \mathrm{X}_{2}+\mathrm{e}
$$

Dimana:

$\mathrm{Y}=$ Hasil Belajar

$\mathrm{X}_{1}=$ Latar belakang pendiidkan orang tua

$\mathrm{X}_{2}$ = Gaya belajar

$\mathrm{a} \quad=$ Konstanta

$\mathrm{b} \quad=$ Koefisien regresi

$\mathrm{e} \quad=$ Kesalahan pengganggu

Untuk mempermudah perhitungan dan pengolahan data, maka analisis regresi ganda dihitung dengan bantuan program SPSS 22.

b. Uji $t$

Uji $t$ digunakan untuk mengetahui besarnya hubungan masing-masing variabel bebas secara individual terhadap variabel terikat. Untuk menguji koefisien hipotesis: $\mathrm{Ho}=0$. untuk itu langkah yang digunakan untuk menguji hipotesa tersebut dengan uji $t$ adalah sebagai berikut :

1) Menentukan Ho dan $\mathrm{Ha}$

Jika Ho: $\beta_{1}=\beta_{2}=\beta_{3}=0$ maka tidak terdapat pengaruh yang signifikan antara variabel independen dan variabel dependen $\mathrm{Ha}: \beta_{1} \neq \beta_{2} \neq \beta_{3} \neq 0$ (terdapat pengaruh yang signifikan antara variabel independen dan variabel dependen). 
2) Menentukan Level of Significance Level of Significance yang digunakan sebesar $5 \%$ atau $(\alpha)=0,05$.

3) Menentukan nilai $t$ ( $t$ hitung) Melihat nilai $t$ hitung dan membandingkannya dengan $\mathrm{t}$ tabel. Jika $t$ hitung $>t$ tabel, maka Ho di tolak dan jika $t$ hitung $<t$ tabel, maka Ho diterima.

4) Menentukan kriteria penerimaan dan penolakan Ho yaitu Jika signifikansi $<0,05$ maka Ho ditolak Jika signifikansi $>0,05$ maka Ho diterima.

\section{HASIL DAN PEMBAHASAN}

\section{Hasil Analisis Deskripsi Latar Belakang Pendidikan Orang Tua, Gaya Belajar dan Hasil Belajar Peserta Didik di MI Maarif NU Sekaran Lamongan}

Statistik deskriptif digunakan sebagai dasar untuk mengetahui dan menguraikan kecendrungan peserta didik berdasarkan jawaban dari masing-masing variabel yaitu latar belakang tingkat pendidikan orang tua, gaya belajar dan hasil belajar peserta didik di MI Maarif NU Sekaran Lamongan. Berikut deskripsi latar belakang pendidikan orang tua, gaya belajar dan hasil belajar peserta didik:

a. Kondisi Latar Belakang Pendidikan Orang Tua Peserta Didik Kelas IV di MI Maarif NU Sekaran Lamongan.

Instrument yang digunakan untuk mengetahui latar belakang tingkat pendidikan orang tua adalah dari dokumentasi yang dimiliki oleh pihak sekolah terkait data peserta didik yang di dalamnya juga memuat data orang tua peserta didik yaitu nama, alamat serta pendidikan terakhir orang tua peserta didik. Data mengenai pendidikan terakhir dari 38 orang peserta didik yang sudah diperoleh kemudian kami klasifikasikan kedalam tiga kategori yaitu rendah sedang dan tinggi dengan ketentuan sebagaimana tabel berikut ini:

Tabel 2. Klasifikasi tingkat pendidikan orang tua peserta didik

\begin{tabular}{llll}
\hline No. & \multicolumn{1}{c}{ Skala } & \multicolumn{1}{c|}{ Batasan } & \multicolumn{1}{c}{ Kategori } \\
\hline 1. & $\mathrm{X}<\mathrm{M}-1 \mathrm{SD}$ & $\mathrm{X}<1,48$ & Rendah \\
\hline 2. & $\mathrm{M}-1 \mathrm{SD} \leq \mathrm{X} \leq \mathrm{M}+1 \mathrm{SD}$ & $1,48 \leq \mathrm{X} \leq 3,189$ & Sedang \\
\hline 3. & $\mathrm{X}>\mathrm{M}+1 \mathrm{SD}$ & $\mathrm{X}>3,189$ & tinggi \\
\hline \multicolumn{3}{l}{ Berdasarkan klasifikasi tersebut maka diperoleh data sebagai berikut: }
\end{tabular}

Tabel 3. Kondisi latar belakang pendidikan orang tua peserta didik

\begin{tabular}{cccccc}
\hline & Frequency & Percent & Valid Percent & Cumulative Percent \\
\hline Valid & Rendah & 7 & 18.4 & 18.4 & 18.4 \\
& Sedang & 30 & 78.9 & 78.9 & 97.4 \\
& Tinggi & 1 & 2.6 & 2.6 & 100.0 \\
& Total & 38 & 100.0 & 100.0 & \\
\hline
\end{tabular}


KARANGAN: Jurnal Kependidikan, Pembelajaran, dan Pengembangan, Vol 02, No 01, Bln Feb, Tahun 2020, Hal 46-63

Adapun deskripsi mengenai tingkat pendidikan orang tua dapat digambarkan dengan diagram batang sebagai berikut:

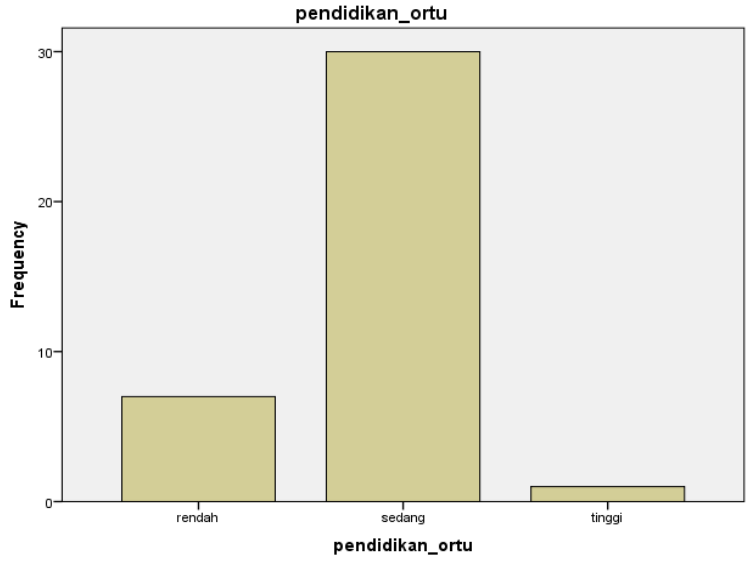

Gambar 1. Kondisi latar belakang pendidikan orang tua peserta didik

Berdasarkan pengolahan data mengenai pendidikan terakhir orang tua yang sudah dikumpulkan dari 38 peserta didik di atas menunjukkan bahwa $18,4 \%$ memiliki tingkat pendidikan yang rendah, $78,9 \%$ orang tergolong pendidikan sedang dan 2,6\% orang tergolong memiliki tingkat pendidikan yang tinggi. Dari porsentase tersebut dapat diketahui bahwa sebagian besar tingkat pendidikan orang tua peserta didik di kelas IV MI Maarif NU Sekaran lamongan tergolong sedang.

b. Kondisi Gaya belajar peserta didik kelas IV di MI Maarif NU Sekaran Lamongan.

Instrument yang digunakan untuk mengidentifikasi gaya belajar peserta didik kelas IV MI Ma'arif NU Sekaran Lamongan adalah dengan menggunakan angket yang terdiri atas 30 item pertanyaan, dimana tiap sub indikator variabel gaya belajar diwakili oleh 10 item pernyataan. Untuk mengetahui kecendrungan gaya belajar peserta didik (visual, auditori dan kinestetik) yaitu skor dari hasil pengisian angket dikelompokkan terlebih dahulu kemudian kita analisis dan hasilnya sebagai berikut:

Tabel 4. Kondisi gaya belajar peserta didik

\begin{tabular}{|c|c|c|c|c|c|}
\hline & & Frequency & Percent & Valid Percent & Cumulative Percent \\
\hline \multirow[t]{4}{*}{ Valid } & Auditory & 19 & 50.0 & 50.0 & 50.0 \\
\hline & Kinestetik & 3 & 7.9 & 7.9 & 57.9 \\
\hline & Visual & 16 & 42.1 & 42.1 & 100.0 \\
\hline & Total & 38 & 100.0 & 100.0 & \\
\hline
\end{tabular}

Berdasarkan alternatif jawaban pernyataan dalam angket yang diberikan kepada 30 responden untuk mengukur variabel gaya belajar $\left(\mathrm{X}_{2}\right)$ dengan 4 alternatif jawaban yaitu selalu (4), sering (3), kadang-kadang (2) dan tidak pernah (1). Kecendrungan 
gaya belajar peserta didik kelas 4 di MI Maarif NU Sekaran Lamongan dapat dilihat melalui diagram sebagai berikut.

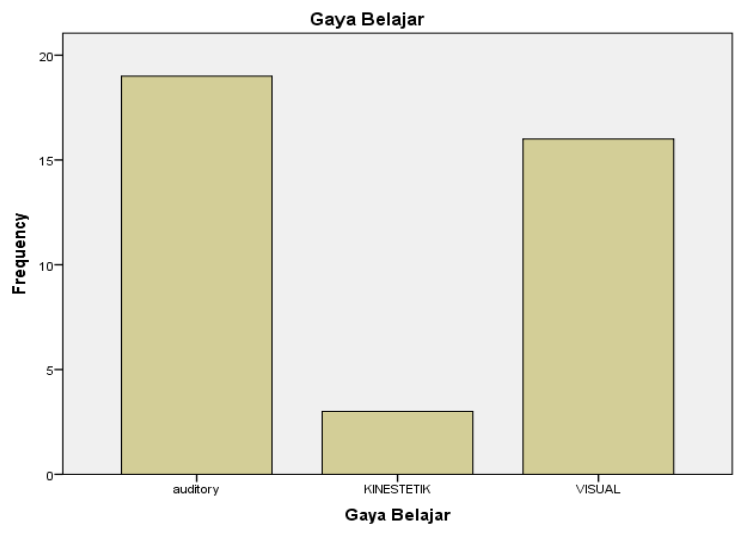

Gambar 2. Kondisi gaya belajar peserta didik

Berdasarkan pengolahan data angket yang sudah disebarkan dan diolah menjadi tabel dan diagram di atas maka bisa kita lihat bahwa peserta didik kelas 4 di MI Maarif NU Sekaran Lamongan sebanyak 19 orang peserta didik cenderung memiliki tipe gaya belajar auditori (50\%) dimana anak dengan gaya belajar ini mereka lebih tertarik menggunakan indra pendengarannya untuk belajar karena itu diperlukan intonasi suara yang bervariasi, merdu serta diselingi musi agar mereka lebih termotivasi dalam mengikuti kegiattan pembelajaran.

Sedangkan ada 16 orang peserta didik dengan prosentase $42,1 \%$ memiliki tipe gaya belajar visual dimana mereka cenderung tertarik untk belajar jika mata mereka dimanjakan. Anak-anak dengan tipe ini lebih bergairah belajar jika melihat obyeknya secara langsung, menonton video, menggunakan alat peraga edukatif atau minimal dengan menggnakan gambar. dan 3 orang peserta didik lainnya dengan tipe gaya belajar kinestetik (7,9\%). Anak-anak dengan gaya belajar kinestetik ini cenderung aktif bergerak, mereka cenderung menyukai kegiatan pembelajaran yang mengeksplorasi aktifitas fisik.

c. Kondisi Hasil Belajar Peserta Didik Kelas 4 di MI Maarif NU Sekaran Lamongan

Instrument yang digunakan dalam mengukur hasil belajar Matematika peserta didik di MI Maarif NU sekaran adalah dengan menggunakan nilai raport ulangan tengah semester genap tahun ajaran 20016/2019 mata pelajaran matematika. Dari hasil raport yang diperoleh skor total harapan terendah adalah 0 dan skor tertinggi adalah 100 dengan KKM 75. Berdasarkan skor harapan dan KKM tersebut bisa diketahui nilai hasil belajar peserta didik dan berapa tingat pemahaman peserta didik terhadap materi yang sudah disampaikan.

Berdasarkan data hasil belajar peserta didik yang sudah dikumpulkan dari 38 peserta didik menunjukkan skor rata-rata hasil belajar peserta didik yang tertinggi adalah 95 sedangkan skor terendah adalah 75. Kondisi hasil belajar peserta didik kelas 4 di MI Maarif NU sekaran adalah sebgai berikut: 
KARANGAN: Jurnal Kependidikan, Pembelajaran, dan Pengembangan, Vol 02, No 01, Bln Feb, Tahun 2020, Hal 46-63

Tabel 5. Klasifikasi Hasil Belajar Peserta Didik

\begin{tabular}{llll}
\hline No. & \multicolumn{1}{c}{ Skala } & \multicolumn{1}{c}{ Batasan } & \multicolumn{1}{c}{ Kategori } \\
\hline 1. & $\mathrm{X}<\mathrm{M}-1 \mathrm{SD}$ & $\mathrm{X}<75,76$ & Rendah \\
\hline 2. & $\mathrm{M}-1 \mathrm{SD} \leq \mathrm{X} \leq \mathrm{M}+1 \mathrm{SD}$ & $75,76 \leq \mathrm{X} \leq 87,4$ & Sedang \\
\hline 3. & $\mathrm{X}>\mathrm{M}+1 \mathrm{SD}$ & $\mathrm{X}>87,4$ & tinggi \\
\hline
\end{tabular}

Berdasarkan klasifikasi tersebut kondisi belajar siswa di MI Maarif NU sekaran adalah sebgai berikut:

Tabel 6. Kondisi hasil belajar matematika peserta didik

\begin{tabular}{cccccc}
\hline & Frequency & Percent & Valid Percent & Cumulative Percent \\
\hline Valid & rendah & 5 & 13.2 & 13.2 & 13.2 \\
& sedang & 26 & 68.4 & 68.4 & 81.6 \\
tinggi & 7 & 18.4 & 18.4 & 100.0 \\
Total & 38 & 100.0 & 100.0 & \\
\hline
\end{tabular}

Adapun deskripsi mengenai tingkat pendidikan orang tua dapat digambarkan dengan diagram batang sebagai berikut:

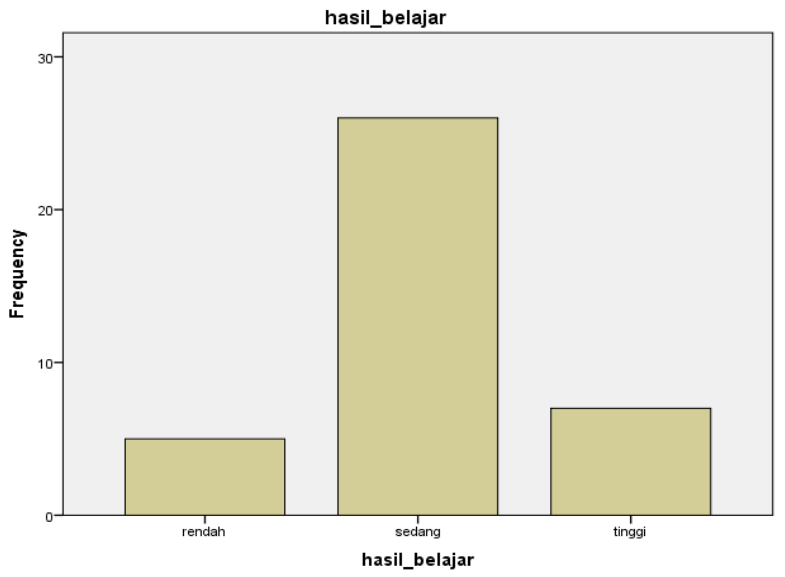

Gambar 3. Kondisi hasil belajar matematika peserta didik

Berdasarkan hasil pengolahan data tentang kondisi hasil belajar peserta didik kelas IV di MI Maarif NU sekaran ada sebanyak 5 orang peserta didik dengan prosentase $13,2 \%$ yang memiliki hasil belajar yang rendah sehingga peran guru dan orang tua sangat diharapkan untuk membina dan meningkatkan hasil belajar eserta didik di MI Maarif NU sekaran.

Sedangkan siswa yang memiliki nilai hasil belajar sedang sebanyak 26 anak dengan prosentasi $68,4 \%$ itu artinya sebagian besar peserta didik sudah mampu medapat nilai matematika baik. Serta peserta didik dengan hasil belajar matematika tinggi sebanyak 7 orang dengan presentasi $18,4 \%$ itu artinya terdapat beberapa anak di MI Maarif NU sekaran yang memiliki nilai hasil belajar yang sangat baik.

Dengan demikian berdasarkan hasil temuan penelitian ini menunjukkan bahwa sebagian besar peserta didik kelas IV di MI Maarif NU sekaran hasil belajar matematikanya tergolong sedang sehingga dapat dikatakan bahwa peserta didik kelas IV di MI Maarif NU Sekaran berhasil dalam belajarnya dan mampu menunjukkan perubahan yang lebih baik. 


\section{Hasil Uji Persyaratan Regresi Latar Belakang Pendidikan Orang Tua, Gaya Belajar dan Hasil Belajar Matematika Peserta Didik Kelas IV di MI Ma'arif NU Sekaran Lamongan}

Sebelum melakukan uji hipotesis terlebih dahulu kita harus melakukan uji persyaratan analisis data atau uji asumsi klasik, artinya sebelum kita melakukan analisis statistik untuk uji hipotesis dalam hal ini adalah analisis regresi maka kita harus melakukan uji asumsi klasik yang meliputi uji normalitas dan uji linearitas.

a. Hasil Uji Normalitas Latar Belakang Pendidikan Orang Tua, Gaya Belajar dan Hasil Belajar Matematika Peserta Didik Kelas IV Di MI Ma'arif NU Sekaran Lamongan.

Uji normalitas merupakan salah satu bagian dari uji persyaratan analisis data atau uji asumsi klasik. Uji normalitas ini digunakan untuk mengetahui normal tidaknya suatu distribusi data, hal ini penting untuk diketahui berkaitan dengan uji statistik yang akan digunakan. Berikut ini adalah hasil uji Onesampel Kolmogorov-Smirnov dengan ketentuan jika sig > 0,05 maka data berdistribusi normal.

Tabel 6. Hasil uji normalitas latar belakang pendidikan orang tua dan gaya belajar terhadap hasil belajar peserta didik.

\begin{tabular}{llr}
\hline & & Unstandardized Residual \\
\hline Normal Parameters & & 38 \\
& Mean & .0000000 \\
Most Extreme Differences & Std. Deviation & 5.70406508 \\
& Absolute & .141 \\
& Positive & .141 \\
Test Statistic & Negative & -.110 \\
Asymp. Sig. (2-tailed) & & .141 \\
\hline a. Test distribution is Normal. & $.053^{\text {c }}$ \\
b. Calculated from data. & \\
c. Lilliefors Significance Correction. &
\end{tabular}

Beradasarkan hasil output SPSS tersebut diketahui bahwa nilai Asymp. Sig.(2-tailed) sebesar 0,053 > 0,05 maka sesuai dengan dasar pengambilan keputusan dalam uji normalitas Kolmogorov-Smirnov di atas dapat disimpulkan bahwa data berdistribusi normal. Dengan demikian, asumsi atau persyaratan normalitas dalam regresi sudah terpenuhi.

b. Hasil Uji Linearitas Latar Belakang Pendidikan Orang Tua, Gaya Belajar Dan Hasil Belajar Matematika Peserta Didik Kelas IV di MI Ma'arif NU Sekaran Lamongan.

Secara umum uji linearitas digunakan untuk mengetahui apakah dua variable mempunyai hubungan yang linear secara signifikan atau tidak. Korelasi yang baik seharusnya memilki hubungan yang linear antara variabel independen (variabel bebas) dan variabel dependen (variabel terikat). Dalam beberapa sumber dinyatakan bahwa uji linearitas ini merupakan syarat sebelum dilakukannya analisis regresi linear. Dasar pengambilan keputusan dalam uji linearitas ini adalah jika nilai Deviation From Linearity sig. > 0,05 maka ada hubungan yang linier secara signifikan antra variabel independent dan variabel dependent sebaliknya jika jika nilai Deviation From Linearity sig. $<0,05$ maka tidak ada hubungan yang linier secara signifikan antra variabel independent dan 
KARANGAN: Jurnal Kependidikan, Pembelajaran, dan Pengembangan, Vol 02, No 01, Bln Feb, Tahun 2020, Hal 46-63

variabel dependent. Lebih jelasnya uji linearitas Latar Belakang Pendidikan Orang Tua, Gaya Belajar Terhadap Hasil Belajar sebagai berikut.

Tabel 7. Hasil uji linearitas latar belakang pendidikan orang tua terhadap hasil belajar peserta didik

\begin{tabular}{|c|c|c|c|c|c|c|c|}
\hline & & & $\begin{array}{l}\text { Sum of } \\
\text { Squares }\end{array}$ & df & Mean Square & $\mathbf{F}$ & Sig. \\
\hline \multirow{2}{*}{$\begin{array}{l}\text { hasil } \\
\text { belajar } \\
*\end{array}$} & \multirow{3}{*}{$\begin{array}{l}\text { Between } \\
\text { Groups }\end{array}$} & (Combined) & 133.913 & 3 & 44.638 & 1.356 & 273 \\
\hline & & Linearity & 46.246 & 1 & 46.246 & 1.405 & .244 \\
\hline \multirow{3}{*}{$\begin{array}{l}\text { Pendid } \\
\text { ikan } \\
\text { orang } \\
\text { tua }\end{array}$} & & $\begin{array}{l}\text { Deviation from } \\
\text { Linearity }\end{array}$ & 87.666 & 2 & 43.833 & 1.331 & .278 \\
\hline & \multicolumn{2}{|c|}{ Within Groups } & 1119.351 & 34 & 32.922 & & \\
\hline & \multicolumn{2}{|l|}{ Total } & 1253.263 & 37 & & & \\
\hline
\end{tabular}

Dari data output SPSS d atas diperoleh nilai Deviation From Linearity sig. adalah 0,278 $>0,05$. Maka dapat disimpulkan bahwa ada hubungan linear secara signifikan antara variabel pendidikan orang tua (X1) dan hasil belajar (Y). Sedangkan hasil uji linearitas gaya belajar dan hasil belajar adalah sebagai berikut:

Tabel 8. Hasil uji linearitas gaya belajar terhadap hasil belajar peserta didik

\begin{tabular}{|c|c|c|c|c|c|c|c|}
\hline & & & $\begin{array}{l}\text { Sum of } \\
\text { Squares }\end{array}$ & df & $\begin{array}{c}\text { Mean } \\
\text { Square }\end{array}$ & $\mathbf{F}$ & Sig. \\
\hline \multirow{5}{*}{$\begin{array}{l}\text { hasil belajar } \\
\text { * gaya } \\
\text { belajar }\end{array}$} & $\begin{array}{l}\text { Between } \\
\text { Groups }\end{array}$ & (Combined) & 76.378 & 2 & 38.189 & 1.136 & .333 \\
\hline & & Linearity & 7.614 & 1 & 7.614 & .226 & .637 \\
\hline & & $\begin{array}{l}\text { Deviation from } \\
\text { Linearity }\end{array}$ & 68.764 & 1 & 68.764 & 2.045 & .162 \\
\hline & \multicolumn{2}{|c|}{ Within Groups } & 1176.885 & 35 & 33.625 & & \\
\hline & \multicolumn{2}{|l|}{ Total } & 1253.263 & 37 & & & \\
\hline
\end{tabular}

Dari data output SPSS di atas diperoleh nilai Deviation From Linearity sig. adalah 0,162>0,05. Maka dapat disimpulkan bahwa ada hubungan linear secara signifikan antara variabel gaya belajar $\left(\mathrm{X}_{2}\right)$ dan hasil belajar $(\mathrm{Y})$.

\section{Pengujian Hipotesis Latar Belakang Pendidikan Orang Tua, Gaya Belajar dan Hasil Belajar Matematika Peserta Didik Kelas IV di MI Ma'arif NU Sekaran Lamongan.}

Pengujian hipotesis ini dilakukan untuk mengetahui ada tidaknya pengaruh latar belakang pendidikan orang tua dan gaya belajar terhadap hasil belajar matematika peserta didik di kelas IV MI Maarif Sekaran Lamongan. Uji hpotesis ini dilakukan dengan menggunakan analisis regresi linear berganda dengan bantuan program SPSS 22 for windows.

a. Hasil analisis regresi linear berganda Latar Belakang Pendidikan Orang Tua, Gaya Belajar dan Hasil Belajar Matematika Peserta Didik Kelas IV di MI Ma'arif NU Sekaran Lamongan. 
Dalam pengolahan data menggunakan regresi linear berganda dilakukan beberapa tahapan untuk mencari pengaruh antra variabel dependen dan variabel independen. Dan diperoleh hasil regresi sebagaimana tabel berikut:

Tabel 9. Hasil Analisis Regresi Berganda

\begin{tabular}{lllrrrrr}
\hline & & \multicolumn{2}{c}{$\begin{array}{c}\text { Unstandardized } \\
\text { Coefficients }\end{array}$} & \multicolumn{2}{c}{$\begin{array}{c}\text { Standardized } \\
\text { Coefficients }\end{array}$} & & \\
\cline { 3 - 6 } Model & & B & Std. Error & Beta & \multicolumn{1}{c}{ t } & Sig. \\
\hline 1 & (Constant) & 77.691 & 3.654 & & 21.26 & .000 \\
& & & & & 2 & \\
& $\begin{array}{l}\text { pendidikan orang } \\
\text { tua }\end{array}$ & 1.311 & 1.190 & .185 & 1.102 & .278 \\
& gaya belajar & .472 & 1.554 & .051 & .304 & .763 \\
\hline
\end{tabular}

Variabel terikat dalam penelitian ini adalah hasil belajar sedangkan variabel bebas dalam penelitian ini adalah tingkat pendidikan orang tua dan gaya belajar. Model regresi berdasarkan hasil analisis di atas adalah:

$$
\begin{aligned}
\mathrm{Y} & =\mathrm{a}+\mathrm{b}_{1} \mathrm{x}_{1}+\mathrm{b}_{2} \mathrm{X}_{2}+\mathrm{e} \\
& =77,691+1,311 \mathrm{X}_{1}+0,472 \mathrm{X}_{2}+\mathrm{e}
\end{aligned}
$$

Adapun interpretasi dari persamaan tersebut adalah sebagai berikut:

1) $\mathrm{a}=77,691$

Nilai konstanta ini menunjukkan bahwa apabila tidak ada variabel bebas (pendidikan orang tua dan gaya belajar) maka variabel terikat yaitu hasil belajar adalah sebesar 77,691. Dalam arti kata hasil belajar bernilai 77,691 sebelum atau tanpa adanya variabel pendidikan orang tua dan gaya belajar (dimana $\mathrm{X}_{1} \mathrm{X}_{2}=0$ ).

2) $\mathrm{b}_{1}=1,311$

Nilai parameter atau koefisien regresi b1 ini menunjukkan bahwa setiap variabel tingkat pendidikan orang tua meningkat 1 satuan, maka hasil belajar akan meningkat sebesar 1,311 kali atau dengan kata lain setiap peningkatan hasil belajar dibutuhkan variabel tingkat pendidikan orang tua sebesar 1,311 dengan asumsi variabel bebas yang lain tetap $\left(\mathrm{x}_{2}\right)$.

3) $\mathrm{b}_{2}=0,214$

Nilai parameter atau koefisien regresi b2 ini menunjukkan bahwa setiap variabel tingkat pendidikan orang tua meningkat 1 satuan, maka hasil belajar akan meningkat sebesar 0,214 kali atau dengan kata lain setiap peningkatan hasil belajar dibutuhkan variabel gaya belajar sebesar 0,214 dengan asumsi variabel bebas yang lain tetap $\left(\mathrm{x}_{1}\right)$

b. Hasil uji t (parsial) Latar Belakang Pendidikan Orang Tua, Gaya Belajar dan Hasil Belajar Matematika Peserta Didik Kelas IV di MI Ma'arif NU Sekaran Lamongan.

Hasil uji t digunakan untuk mengetahui apakah variabel bebas yaitu latar belakang pendidikan orang tua dan gaya belajar secara parsial (sendiri-sendiri) memiliki pengaruh yang signifikan terhadap variabel terikat hasil belajar, serta untuk mencari variabel bebas manakah yang paling dominan pengaruhnya. 
KARANGAN: Jurnal Kependidikan, Pembelajaran, dan Pengembangan, Vol 02, No 01, Bln Feb, Tahun 2020, Hal 46-63

Untuk menguji koefisien hipotesis: $\mathrm{Ho}=0$. untuk itu langkah yang digunakan untuk menguji hipotesa tersebut dengan uji t adalah sebagai berikut :

1) Menentukan Ho dan $\mathrm{Ha}$

Ho : $\beta 1=\beta 2=\beta 3=0$ ( tidak terdapat pengaruh yang signifikan antara variabel independen dan variabel dependen) Ho : $\beta 1 \neq \beta 2 \neq \beta 3 \neq 0$ ( terdapat pengaruh yang signifikan antara variabel independen dan variabel dependen).

2) Menentukan Level of Significance Level of Significance yang digunakan sebesar $5 \%$ atau $(\alpha)=0,05$

3) Menentukan nilai $t$ ( $t$ hitung), Melihat nilai $t$ hitung dan membandingkannya dengan $t$ tabel.

a) Jika $t$ hitung $\geq t$ tabel, maka Ho ditolak dan Ha diterima, artinya variabel bebas $\left(\mathrm{x}_{1} \mathrm{x}_{2}\right)$ yaitu latar belakang pendidikan orang tua dan gaya belajar secara parsial berpengaruh terhadap variabel terikat $(\mathrm{Y})$ yaitu hasil belajar.

b) Jika $t$ hitung $\leq t$ tabel, maka Ho diterima dan Ha ditolak, artinya variabel bebas $(\mathrm{x} 1 \times 2)$ yaitu latar belakang pendidikan orang tua dan gaya belajar secara parsial tidak berpengaruh terhadap variabel terikat (Y) yaitu hasil belajar.

c) Menentukan kriteria penerimaan dan penolakan Ho sebagai berikut : Jika signifikansi $<0,05$ maka Ho ditolak Jika signifikansi $>0,05$ maka Ho diterima.

Tabel 10. Uji parsial $t$

\begin{tabular}{|c|c|c|c|c|c|c|}
\hline \multirow{2}{*}{\multicolumn{2}{|c|}{ Model }} & \multicolumn{2}{|c|}{$\begin{array}{c}\text { Unstandardized } \\
\text { Coefficients } \\
\end{array}$} & \multirow{2}{*}{$\begin{array}{c}\begin{array}{c}\text { Standardized } \\
\text { Coefficients }\end{array} \\
\text { Beta }\end{array}$} & \multirow[b]{2}{*}{$\mathbf{T}$} & \multirow[b]{2}{*}{ Sig. } \\
\hline & & B & Std. Error & & & \\
\hline \multirow[t]{3}{*}{1} & (Constant) & 77.691 & 3.654 & & 21.262 & .000 \\
\hline & pendiidkan orang tua & 1.311 & 1.190 & .185 & 1.102 & .278 \\
\hline & gaya belajar & .472 & 1.554 & .051 & .304 & .763 \\
\hline
\end{tabular}

a. Dependent Variable: hasil belajar

Berdasarkan hasil analisis regresi tabel di atas diperoleh hasil sebagai berkut:

1) Variabel latar belakang pendidikan orang tua memiliki thitung sebesar $1,102<1,68$ dengan signifikasi 0,278 $>0,05$. Karena thitung $<\mathrm{t}$ tabel dan sig.> 5\% maka dapat disimpulkan secara parsial Variabel latar belakang pendidikan orang tua tidak berpengaruh terhadap hasil belajar matematika peserta didik kelas 4 di MI Ma'arif NU sekaran lamongan.

2) Variabel gaya belajar memiliki thitung sebesar 0,304 dengan signifikasi 0,763. Karena thitung $<\mathrm{t}$ tabel dan sig. $>5 \%$ maka dapat disimpulkan secara parsial variabel gaya belajar tidak berpengaruh terhadap hasil belajar matematika peserta didik kelas IV di MI Ma'arif NU Sekaran Lamongan. 


\section{Kondisi Latar Belakang Pendidikan orang tua, Gaya Belajar dan Hasil Belajar Matematika Peserta Didik Kelas IV MI Ma'arif NU Sekaran Lamongan}

a. Kondisi Latar Belakang Pendidikan Orang Tua Peserta Didik

Berdasarkan data yang diperoleh peneliti dari dokumentasi yang dimiliki oleh pihak sekolah terkait pendidikan terakhir orang tua peserta didik yang kemudian data tersebut diolah dan diklasifikasikan, maka hasil dari pengolahan data tersebut menunjukkan bahwa sebagaian besar pendidikan terakhir orang tua peserta didik kelas IV di MI Ma'arif Sekaran Lamongan adalah tergolong sedang dengan prosentase $78,9 \%$, sedangkan tingkat pendidikan yang rendah sebanyak $18,4 \%$ dan $2,6 \%$ orang tergolong memiliki tingkat pendidikan yang tinggi.

b. Kondisi Gaya Belajar

Berdasarkan hasil penyebaran angket yang diberikan kepada 38 responden dengan dengan 4 alternatif jawaban yaitu selalu (4), sering (3), kadang-kadang (2) dan tidak pernah (1) untuk mengukur variabel gaya belajar (X2), maka berdasarkan hasil pengolahan data angket yang sudah disebarkan bisa kita lihat bahwa peserta didik kelas IV di MI Maarif NU Sekaran Lamongan sebanyak 19 orang peserta didik cenderung memiliki tipe gaya belajar auditori (50\%) dimana anak dengan gaya belajar ini mereka lebih tertarik menggunakan indra pendengarannya untuk belajar karena itu diperlukan intonasi suara yang bervariasi, merdu serta diselingi music agar mereka lebih termotivasi dalam mengikuti kegiattan pembelajaran. Sedangkan ada 16 orang peserta didik dengan prosentase $42,1 \%$ memiliki tipe gaya belajar visual dimana mereka cenderung tertarik untuk belajar jika maa mereka dimanjakan. Anak-anak dengan tipe ini lebih bergairah belajar jika melihat obyeknya secara langsung, menonton video, menggunakan alat peraga edukatif atau minimal dengan menggnakan gambar dan 3 orang peserta didik lainnya dengan tipe gaya belajar kinestetik (7,9\%). Anak-anak dengan gaya belajar kinestetik ini cenderung aktif bergerak, mereka cenderung menyukai kegiatan pembelajaran yang mengeksplorasi aktifitas fisik.

c. Kondisi Hasil Belajar

Kondisi hasil belajar peserta didik kelas IV di MI Maarif NU sekaran ada sebanyak 5 orang peserta didik dengan prosentase 13,2\% yang memiliki hasil belajar yang rendah sehingga peran guru dan orang tua sangat diharapkan untuk membina dan meningkatkan hasil belajar eserta didik di MI Maarif NU sekaran.Sedangkan siswa yang memiliki nilai hasil belajar sedang sebanyak 26 anak dengan prosentasi $68,4 \%$ itu artinya sebagian besar peserta didik sudah mampu medapat nilai matematika baik. Serta peserta didik dengan hasil belajar matematika tinggi sebanyak 7 orang dengan presentasi $18,4 \%$ itu artinya terdapat bebrapa anak di MI Maarif NU sekaran yang memiliki nilai hasil belajar yang sangat baik.

Berdasarkan data tersebut penulis bisa simpulkan bahwa peserta didik kelas IV MI Ma'arif Sekaran Lamongan cenderung berhasil dalam belajar matematika itu bisa kita lihat dari hasil belajar mereka yang sudah melampaui kriteria ketuntasan minimal (KKM) yang sebelumnya sudah ditentukan oleh pihak sekolah dan sebagian besar hasil belajar mereka tergolong sedang. 
KARANGAN: Jurnal Kependidikan, Pembelajaran, dan Pengembangan, Vol 02, No 01, Bln Feb, Tahun 2020, Hal 46-63

\section{Pengaruh Latar Belakang Pendidikan Orang Tua Terhadap Hasil Belajar Peserta Didik}

Berdasarkan hasil analisis yang sudah dilakukan sebelumnya terkait latar belakang pendidikan orang tua dan hasil belajar matematika peserta didik kelas IV MI Ma'arif NU Sekaran Lamongan, maka diperolah nilai variabel latar belakang pendidikan orang tua memiliki thitung sebesar 1,102 < 1,68 dengan signifikasi $0,278>0,05$. Karena thitung < ttabel dan sig. 0,278>0,05 maka dapat disimpulkan secara parsial variabel latar belakang pendidikan orang tua tidak berpengaruh terhadap hasil belajar matematika peserta didik kelas IV di MI Ma'arif NU Sekaran Lamongan.

Hubungan latar belakang tingkat pendidikan orang tua terutama ibu dengan hasil belajar menurut beberapa ahli dianggap keterkaitan, yaitu jika pendidikan terakhir orang tua baik maka akan mengarahkan pada kebiasaan belajar yang baik dan mengarahkan pada gaya belajar yang terarah. Hal ini mengakibatkan hasil belajar siswa meningkat, sebaliknya jika pendidikan terakhir orangtua cenderung kurang maka akan lebih cuek dan tidak mau tahu atas permasalahan yang ada di dalam sekolah mengenai hasil belajar siswa yang cenderung kurang (Tety, dkk, 2016).

Sementara di pihak lain beberapa fakta menunjukkan bahwa terkadang latar belakang pendidikan yang tinggi tidak menjamin orang tua akan memberikan perhatian dan motivasi terhadap anaknya hal ini dikarenakan mereka memiliki keterbatasan waktu akibat pekerjaan yang mereka lakukan dan adapula orang tua yang memiliki latar belakang rendah namun memiliki kesadaran yang tinggi akan pentingnya pendidikan bagi putra dan putri mereka, sehingga mereka mencari informasi terkait anak-anak dan meluangkan waktu mereka untuk membantu dan mendampingi putra dan putri mereka dalam menyelesaikan tugas belajarnya dan karena perhatian yang lebih tersebut menjadikan putra dan putri mereka memiliki motivasi belajar yang tinggi sehingga hasil belajar merekapun tinggi dan tak kalah dengan anak yang memiliki orang tua dengan latar belakang tingkat pendidikan yang tinggi.

Hal tersebut sejalan dengan penelitian yang dilaksanakan di India, Chile, Iran dan Thailand yang dilaporkan oleh Thorndike menjelaskan bahwa latar belakang keluarga itu dapat menjelaskan perubahan prestasi belajar antara 1,5\% sampai $8,7 \%$. Jika dikontrol dengan indikator-indikator yang berasal dari sekolah seperti kualitas pengajaran, fasilitas sekolah, jumlah siswa dalam kelas dan sebagainya, hasil tes menunjukkan sumbangan latar belakang keluarga tidak signifikan (Iif dan Sofan, 2014).

\section{Pengaruh Gaya Belajar Terhadap Hasil Belajar Peserta Didik}

Setiap manusia yang lahir ke dunia ini selalu berbeda satu sama lainnya. Baik bentuk fisik, tingkah laku, sifat, maupun berbagai kebiasaan lainnya. Tidak ada satupun manusia yang memiliki bentuk fisik, tingkah laku dan sifat yang sama walaupun kembar sekalipun. Suatu hal yang perlu kita ketahui bersama adalah bahwa setiap manusia memiliki cara menyerap dan mengolah informasi yang diterimanya dengan cara yang berbeda satu sama lainnya. Ini sangat tergantung pada gaya belajarnya. Gaya belajar sangat dibutuhkan dalam bidang pendidikan karena digunakan untuk mencari jalan keluar agar belajar menjadi hal yang mudah 
dan menyenangkan agar hasil belajar siswa meningkat. Jika siswa dapat mengenali gaya belajarnya sendiri maka siswa dapat mengelola pada kondisi apa, di mana, kapan dan bagaimana siswa tersebut dapat memaksimalkan belajarnya yang akan mengakibatkan hasil belajar siswa meningkat.

Berdasarkan hasil pengolahan data dengan bantuan SPSS for windows maka diketahui bahwa variabel gaya belajar memiliki thitung sebesar 0,304 dengan signifikasi 0,763 . Karena thitung $<\mathrm{t}$ tabel dan sig.> 5\% maka dapat disimpulkan bahwa secara parsial gaya belajar tidak berpengaruh terhadap hasil belajar matematika peserta didik kelas IV di MI Ma'arif NU sekaran lamongan. Hal ini mungkin di akibatkan adanya variasi pembelajaran yang dilakukan oleh guru sehingga hasil belajar peserta didik dapat merata.

\section{KESIMPULAN DAN SARAN}

Kesimpulan yang dapat diperoleh dari penelitian ini adalah sebagai berikut: 1) Kondisi latar belakang pendidikan orang tua peserta didik berada pada kategori sedang itu artinya sebagian besar orang tua peserta didik memilki dasar pendidikan yang memadai untuk bisa membimbing dan mengarahkan putra putrinya untuk mencapai hasil belajar yang lebih baik. Sedangkan gaya belajar peserta didik mayoritas adalah auditory, anak dengan gaya belajar auditory ini cenderung memanfaatkan indra pendengarannya untuk memahami apa yang dia pelajari mereka sangat mengandalkan telinganya untuk mencapai kesuksesan belajar, misalnya dengan cara mendengar seperti ceramah, radio, berdialog, dan berdiskusi. Selain itu, bisa juga mendengarkan melalui nada (nyanyian/lagu); 2) Latar belakang pendidikan orang tua memiliki thitung sebesar 1,102<1,68 dengan signifikasi 0,278 > 0,05. Karena thitung < ttabel dan sig. 0,278>0,05 itu artinya secara parsial variabel latar belakang pendidikan orang tua tidak berpengaruh terhadap hasil belajar matematika peserta didik; 3) Berdasarkan hasil pengolahan data maka diketahui bahwa variabel gaya belajar memiliki thitung sebesar 0,304 dengan signifikasi 0,763. Karena thitung < t tabel dan sig.> 5\% itu artinya secara parsial gaya belajar tidak berpengaruh terhadap hasil belajar matematika peserta didik.

Berdasarkan hasil penelitian yang dilakukan oleh peniliti maka ada beberapa saran yang ingin peneliti sampaikan, antara lain: 1) Untuk guru, Guru harus dapat mengetahui gaya belajar peserta didik dan mengarahkan siswa sesuai dengan gaya belajar masing-masing sesuai dengan karakteristik siswa agar hasil belajar siswa meningkat; 2) Untuk orang tua, Bagi orangtua terutama ibu hendaknya memberikan perhatian kepada anaknya dengan memantau anaknya dalam hal kegiatan belajar dan orangtua juga harus aktif dalam mengarahkan yang baik bagi anaknya; 3) Untuk siswa, Saran untuk siswa yaitu untuk memperoleh hasil belajar yang baik yaitu dengan mengetahui gaya belajar dengan memilih cara belajar yang cocok bagi dirinya. 
KARANGAN: Jurnal Kependidikan, Pembelajaran, dan Pengembangan, Vol 02, No 01, Bln Feb, Tahun 2020, Hal 46-63

\section{DAFTAR PUSTAKA}

Bobby DePorter dan Mike Hernacki. (2013). Quantum Learning: Membiasakan Belajar Nyaman dan Menyenangkan. Bandung: Kaifa Learning.

Iif dan Sofan. (2014). Pengembangan dan Model Pembelajaran Tematik Integrative. Jakarta: PT Prestasi Pustakarya.

Prihandoko, A.C. (2006). Pemahaman Dan Penyajian Konsep Matematika Secara Benar dan Menarik. Jakarta: Depdiknas

Purwanto. (2013). Evaluasi Hasil Belajar. Yogyakarta: Pustaka Pelajar.

Sudaryono, dkk . (2013). Pengembangan Instrument Penelitian Pendidikan. Yogyakarta: Graha Ilmu

Sudirman, A.M. 2010. Interaksi Dan Motivasi Belajar Mengajar. Jakarta. Raja Grafindo Persada.

Sukiyanto \& Tsalitsatul M.. (2019). Metodelogi Penelitian Pendidikan. Ilalang: Lamongan.

Sukiyanto (2018). Pengembangan rencana pembelajaran matematika dengan model kooperatif tipe stad dan teori Vygotsky. de Fermat: Jurnal Pendidikan Matematika. 1(2). 31-41.

Sulistyaningsih, S. (2015). Kesiapan Bersekolah Ditinjau dari Jenis Pendidikan Pra Sekolah Anak dan Tingkat Pendidikan Orangtua. Jurnal Pemikiran dan Penelitian Psikologi, (Online), 1 (1): 01-07, (http://www.usu.ac.id), diakses 02 Mei 2019.

Tety dkk. (2016). Jurnal Pendidikan: pengaruh latar belakang tingkat pendidikan orangtua dan gaya belajar terhadap hasil belajar siswa pada kelas iv sdn kecamatan sananwetan kota blitar, (Online). Vol. 1 No. 3

Winarsunu T. (2006). Statistik Dalam Penelitian Psikologi dan Pendidikan, Malang: UMM Press

Undang-Undang Nomor 20 Tahun 2003. Tentang Sisdiknas. Jakarta: Departemen Pendidikan Nasional RI.

Zainuddin, F. (2011). Pedoman Pendidikan Modern. Solo:PT Tiga Serangkai Pustaka Mandi 